"Vox Patrum" 6/1986/ z, 11

\title{
KSIĄŻKI PATRYSTYCZNE WYDRUKOWANE W OFICYNACH POLSKICH DO POEOWY XVI W.
}

W okresie średniowiecza, poza św. Augustynem, stosunkowo mato zajmowano sie systematycznym studium myśli teologicznej ojców Kośc1oła 1 pisarzy starochrześcijańskich, zadowalając sie raczej wyciagami z ich dziez/tzw. catenae/. Sytuacja ta zmieniła sije na przełomie XV 1 XVI w., a zwłaszcza w wieku XVI. Epoka renesansu 1 wpływ humanizmu, jako kierunku ideologicznego nawiazujacego do starozytności oraz reformacja 1 kontrreformacja sprzyjały badaniom nad ojcami Kośc1oła 1 pisarzami starochrześcijańskimi. Podczas sporów reformacyjnych korzystano szeroko z $1 \mathrm{ch}$ myśli, odwołujac sie niejednokrotnie do nich zarómno w celu wyjaśnienia pewnych kwestil teologiczno-filozoficznych, jak 1 w celach polemicznych. Często też, choć nie zawsze, zainteresowanie to było umotywowane nowymi prądami w teologil.

Jednym z pierwszych dzieł wielkich Doktorów Kościoła, wytłoczonym prawdopodobnie w Polsce, były "Sermones" papieża Leona I $1+460 /{ }^{1}$, wydrukowane przez anonimowego typograra między 1477 a 1478 rokiem. Dzieło to juz w średniowleczu cieszyło sie wielka popularnościa: ustawicznie je przepisywano, a w XV w. doczekało sie aż 8 wydań drukiem ${ }^{2}$. Wspomniana publikacja anonimowego drukarza różni sie jednak zasadniczo od wydań zachodnich, zawierajacych - oprócz dedykacj1 wydawcy biskupa Aleril Jana Andrzeja de Bussi,

1 Por. Katalog nr 4. /przy końcu artykułu/.

2 A. Lewicka-Kamińska, Nieznany drukarz XV w. tzw. Typographus Leonis I papae Sermones, n: 500-lecie polskiego słowa drukowanego na Sizsku, Wrocław $1978,45$. 
dla papieza Piusa II 1 rejestru kazań - jeszcze 5 listów, z których plerwszy umieszczono wśród kazań, a cztery następne dołączono na końcu. Takich dodatków w wydaniu Anonima brakuje, a zamiast nich zawiera ono kazanie o Absalomie oraz "In nativitate sanctorum septem fratrum Machabeorum", których brak jest wielu rekopisach, a w drukach zachodnich w ogóle ich nie ma. W polskim wydaniu nie ma tez spisu treści. Wskutek tego "Sermones" naszego Anonima zamiast 96 zawieraja 94 kazania, które mają zmienioną kolejnośc, układ a miejзcami 1 tekst ${ }^{3}$. Wszystko wskazuje na to, ze podstawa tej edycji by $z$ rękopis zachowany $w$ Bibliotece Jagiellońskiej 4 , który ma taki sam układ treści ${ }^{5}$.

Wielu najwybitniejszych humanistów występowało w obronie relig11 1 najwyzszych wartości ludzkich, odwołując siz przy tym do starożtnych powag Kościoła, przede wszystkim św. Augustyna $/+430 /$. Biskup Hippony zajmowal poczesne miejsce wśród ojców, zarówno w komentarzach do Pisma św. 1 do "Sentencji", jak 1 we wszelkiego rodzaju pismach religijnych. Juz $w$ XV w. publikowano wielokrotnie - Europie jego pisma. Do r. 1500 drukowano je aż 178 razy ${ }^{6}$.

Juz u zarania polskiego drukarstwa wytłoczono zbiór rozpraw 6́n. Augustyna pod wspólnym tytułem "Omnes libri beati Augustini Aure111: De doctrina christiana tres, praeter quartum qui tractat de modo pronunciandi sermones catholicos"7. Według wydawców "Incunabula Poloniae" zbiór ten zostal wydrukowany ok. $1476 \mathrm{r}$. przez pierwszego polskiego typografa Kaspra Straubego ${ }^{8}$. Przypuszczalna date podano na podstawie dzieła z zakresu prawa kanonicznego Franciszka de Platena "Opus restitutionum", w którym na końcu wymieniono date 1475 r., a miejsce druku na podstawie dzieła "Expla-

\footnotetext{
3 Tamze.

4 Rkps 1439.

5 Lew1cka-Kamińska, art. cyt., 45.

6 F. Kopera, Spis druków epoki Jagiellońskiej w zbiorze E. hr. Hutten-Czapsk1ego w Krakowie, Kraków 1900, 1.

T Por. Katalog $\mathrm{nr} 2$.

8 Incunabula, quae in bibliothecis Poloniae asservantur, moderante A. Kawecka-Gryczowa composuerunt M. Bohonos et E. Szandorowska, Vratislaviae 1970, poz. 616.
} 
natio in Psalterium" Jana Torquemady, gdzie na końcu widnieje nazwa "Cracis". K. Estreicher, który zajął się tym problemem w swojej pracy doktorskiej, wykluczył niemieckiego typografa Zainera, ale nie udało mu się ustalić prawdziwego drukarza ${ }^{9}$ ten bowiem zwyczajem óredntowlecznym nie umieszczał swojego nazwiska na zadnym $z$ druḱw. Nazwisko typografa przyjmuje sie dzisiaj na podstawie odnalezionej przez Bolesława Ulanowskiego notatki w aktach sadu biskupiego w Krakowie ${ }^{10}$.

Powyzsze dzieło św. Augustyna w latach 1472-1487 wydrukowano w Europie aż $25 \mathrm{razy}^{11}$. Swiadczy to niewątpliwie o niezwykłej popularności pism tego 0jea Kościołe v omawianym okresie. Druk krakowski zawiera w sobie 14 różnych rozpraw św. Augustyna, a mianowicie: "De doctrina christiana", "De natura boni contra Manichaeos", "De vera et ralsa paenitentia", "Spaeculum", "De fide ad Petrum diakonum", "Soliloquia", "De fuga mulierum", "De contemptu mund1", "De corruptione et gratia", "De dogmatibus ecclesiasticis", "De disciplina christiana", "De cura pro mortuis gerenda", "De conelictu vitiorum et virtutum", "De praedestinatione sanctorum".

Druk ten jest bardzo starannie wykonany, tłoczony czcionkami gotyckimi, choć nie wydrukowano w nim inicjałów, zostawiajac miejsce dla lluminatorów. Na temat tego dzieła ukazało się juz wiele opraoowań, które wymieniaja autorzy "Drukarzy dawnej Polskin"12.

Powyższy wybór pism św. Augustyna został wydrukowany polsce do poł. XVI $\pi$. tylko ten jeden raz. Powtórnie wytłoczono we Wrocławiu w oflcynie Andrzeja Winklera w 1541 r. tylko "Soliloquia"13. Typograf wrocławski wydrukował tę książke jako lekturę dla uczniów ${ }^{14}$,

9 K. Estreicher, Gunter Zainer i Swiętopełk Fiol, Warszawa 1867.

10 H. Szwejkowska, Książka drukowana XV-XVIII wieku. Zarys hıstoryczny, Wrockaw 1980, 45, przyp. 15.

11 Kopera, dz. cyt., 1.

12 Drukarze dawnej Polski od XV do XVIII wieku, t. 1: Małopolska Cz. 1: W1ek XV-XVI, Praca zbior. pod red. A. Kaweckiej-Gryczowej, Wrockaw 1983, 223-225.

13 Por. Katalog nr 34.

14 M. Burbianka, Andrzej Winkler - drukarz nrocławski XVI wieku. "Rocznik1 Biblioteczne" 4/1960/ z. 3-4, 411. 
na co faktycznie się nadawała, poniewaz rozwaźania o Bogu 1 duszy zostały przez Biskupa Hippony ujęte w przejrzysty 1 logiczny tok myśl1, jak to słusznie podkreślıł sam Winkler we wstępie ${ }^{15}$.

W Interesującym nas okresie jeszcze pięć razy sįgano do dziez św. Augustyna, z których dwa okazały się w czasach nowszych pismami Innych autorów, a dzisiaj zalicza się je do książek pseudoaugustyńskich.

Pewnymi dziełami św. Augustyna wydrukowanymi w Polsce do 1550 r. były: "De vita christiana ad sororen suam viduam liber unus", "De moribus Ecclesiae catholicae et de moribus Manicheorum" oraz "De musica dialogi VI Erasmi /Ciołek/abbatis Mogilensis auspicio editi per Sebastianum de Felstin artium baccalarium et Sanocensis ecclesiae paroccum"16. Plerwsze z nich wydrukował Hieronim Hietor w 1529 r. z przedmową Walentego Ecka, szwajcarskiego humanisty działajzcego w Polsce, dla Michała Falkenera z Wrocławia, profesora Akademii Krakowskiej. Dwa następne tytuły nie zachowały się w Polskich bibliotekach. "De moribus Ecclesiae" znamy z informacji podanej przez Janockiego, dzięki której wiemy, że ksiażkę tę wydrukował Florian Ungler na zlecenie biskupa krakowskiego 12 czerwca 1530 r., a do druku przygotował ją kanonik lwowski Jan Cervus z Tucholi / ok. 1557/17 . o dziele zaś "De musica" informuje nas Bstreicher, który jednocześnie podaje, że wydrukował je Hieronim Wletor w 1536 roku $^{18}$.

Istnieje duze prawdopodobieństwo, że interesowanie sie św. Augustynem przez naszych drukarzy $w$ XVI $w$. było spowodowane oddziaływaniem Erazma z dotterdamu $/+1536 / 19$. Tak zaś Hieronim Wietor, Jak 1 Andrzej Winkler, byl1 gorz̨cymi entuzjastami niderlandzk1ego humanisty ${ }^{20}$. Zaginione "De moribus Ecclesiae" tez wydano pod

15 Por. Karta A2 $\mathrm{r}$.

16 Por. Katalog $\mathrm{nr} 18,19122$.

17 /J. D. Janock1/, Janosciana sive clarorum atque llistrium Poloniae auctorum maecenatumque memoriae miscellae, Varsaviae 1776, 34 .

18 Estr XII, 293.

190 wyraźnym wpływie św. Augustyna na Erazma pisze J. Domańsk1, Od tłumacza, w: Erazm z Rotterdamu, Trzy rozprawy. Zachęta do r1lozofil chrześcijańskiej, Metoda prawdziwej teologil, zboźna b1es1ada. Przekł. 1 oprac. J. Domańsk1, Farszawa 1960, 25-27. o Wietorze por. Drukarze dawnej Polsk1, dz. cyt., 337: 0 Hin- 
patronatem erazmiańczyka - Piotra Tomickiego ${ }^{21}$.

Erazm z Hotterdamu cenił jednak najwięcej z ojców Kościoła św. Hieronima $/+419 / 22$, a następnie św. Jana Chryzostoma $/+407 / 23$, tak ze niemal wszystkie ówczesne polskie publikacje dzieł tych Doktorów Kościoła zostały wydrukowane przy jego współpracy lub za jego zachęta. Wydawano je pod jego wpływem wrakowle 1 we Wrocławiu, gdy w latach dwudziestych XVI stulecia zaistniały po temu odpowiednie warunki, a mianowicie dostateczna znajomość języka greckiego 1 poparcie ze strony episkopatu polskiego, zwraszcza wspomnianego Piotra Tomickiego 1 Piotra Gamrata $/+1545 / 24$. Mimo opozycj1 w niektórych kołach teologów, upatrujacych w studiach klasycznych źródło heretyckich nowinek, biskup Tomicki popierał je zdecydowanie na Akademil Krakowskiej ${ }^{25}$. Wielka role w budzeniu zalnteresowań twórczością Brazma z Rotterdamu na Akademil Krakowskiej odegrał tez angielski humanista Leonard Cox /+ 1549/. Erazmiańskie upodobania Coxa znalazły swój wyraz w opublikowaniu dwóch listów ́́w. Hieronima z tekstu zweryfikowanego przez Rotterdamczyka. Pierwszy $z$ nich wydrukowal Hieronim Wietor $1518 \mathrm{r}$. pt. "Epistola ad Rusticum Monachum, qua vivendi formam praescribit" ${ }^{26}$, drugi-ten sam impresor w $1519 \mathrm{r}$. publikacji pt. "Aliquot epistolae" 27 , gdzie na karcie tytułowej| umieścił elegię innego entuzjasty Erazma - Rudolfa Agrykoli ${ }^{28}$.

klerze por. H. Barycz, Znaczenie Uniwersytetu Krakowskiego w poczatkach rozwoju erazmianizmu $w$ Polsce, "Zeszyty Naukowe Universytetu Jagiellońskiego" 33/1971/: Erazmiana Cracoviensia. W 500-lecie urodzin Erazma $z$ ilotterdamu $/ 1469-1536 /, 36$.

21 W. Szelińska, Wokół krakowskich przyjaciół ksiazzki erazmianskiej wieku Wielkiego lolendra, tanze, 40 i 41.

22 S. Swiezawski, Dzieje filozofil europejskiej XVI wieku, t. IV: Bóg, Warszawa' 1979, 195.

23 Tamze.

24 J. Fijałek, Przekłady pism św. Grzegorza z Nazjanzu w Polsce. Studium o patrystyce naszej, "Polonia Sacra" 1/1918/, 47.

25 J. Czerniatowicz, Bazyli Wielki w nurcie humanistycznym w Polsce. "Eos" 40/1982/, 75.

26 Por. Katalog nr 8.

27 Por. Katalog nr 9.

28 Por. "Epistolas Hieronymi lectissimas, Quibus suum probe nitorem reddidit Erasnus 11le; quo nil absolutius 
Cox przyczynił się równiez do wydania trzeciego listu św. Hieronima pt. "De custodia virginitatis" wytłoczonego przez Wietora w 1519 roku $^{29}$. Druk ten Jednak zachował sie w stanie zdefektowanym w 0ssolineum ${ }^{30}$, a jego lokalizacja nie była znana Estreicherowi ${ }^{31}$. IN liście tym Hieronim pisze, ze dziewiczy Chrystus 1 Jego dziewicza Matka dali przykład postźpowania dla obu płci. Równiez Apostołowie byli ludźmi dziewiczymi. Stąd tez biskupi, kapłani 1 diakoni są dziś także wyblerani jako dziewice lub wdowcy, a po otrzymaniu kapłaństwa, czyści na zawsze.

Nim przejdziemy do jednego z najważniejszych druków ów. Hieronima, opublikowanego razem z dziełem św. Bazylego, nalezy wspomnieć o wytłoczonym przez Kaspra Elyana we Wrocławiu między 1476 a 1482 r. liście Strydończyka pt. "Epistola ad Paulinum Presbiterum"31, który stanowił dodatek do głównego dzieła Jana Gersona pt. "De modo vivendi omnium fldelium". Celem wydawcy było prawdopodobnie pragnienie podkreślenia znaczenia zasadniczego dzieła Gersona poprzez list św. Hieronima, wtórym ten Doktor Kościoła zaleca kapłanowi Paulinowi gorliwość w posłudze duszpasterskiej.

Zupełnie inny charakter miała "Epistola divi IIIeronymi ad magnum oratorem" załaczona do dzieła św. Bazylego pt. "De evolvendis libris"32, wydrukowanego razem przez Wietora w 1534 roku. 0 wydanie tych dziel postarał siz Maciej IValerian z Farszawy/Praedicatorius/ / 1547/, który pragną wykorzystać nyśl1 Doktorów Koścloła w pewnym określonym celu. otóz - jak już wspomniałem w XVI w. zrodziła się groźna opozycja wśród niektórych polskich teologów, upatrujących w studiach klasycznych źródła heretyckich nowinek. Opozycja ta nasiliła się szczególnie po wystąpieniu Marcina Lutra w $1517 \mathrm{r}$. , kiedy to na Uniwersytecie Jagiellońskim zniesiono nawet

Sol inter homines hocce vidit seculo. Tibi, candidissime lector, expressit suis Bellissimis typis Vietor optimus, Apud inclytam Poloniae Cracoviam, Cupiens, ut hoc doctore discas plenius Christum sapere, Christum loqui, Christum insuper Vitaque moribusque recte effingere".

29 Por. Katalog $\mathrm{nr} 10$.

30 Sygn. XVI. Qu. 1733.

31 Por. Katalog $\mathrm{nr} 3$.

32 Por. Katalog $\mathrm{nr}, 20$. 
na jakí́ czas naukę języka greckiego, który jednak wkrótce przywrócono dzięki Tomickiemu. Ofiarą ataku opozycjonistów padł takze Praedicatortus za przeprowadzenie wykładów na temat "Satyr" Horacego ${ }^{33}$. Do obrony miały mu posłużyé wspomniane wyzej pisma Bazylego 1 Hieronima. Był to tradycyjny przekład z jęzka greckiego dokonany przez znakomitego grecystę włoskiego Leonarda Bruni'ego, ucznia pierwszego nauczyciela grek1 w Ital11 Manuela Chrysolorasa ${ }^{34}$. Liczne późniejsze teksty, tak znajdujące się rękopisach, jak 1 mydrukowane, zawierają woizzz ten sam przekład Brun1'ego. "De evolvendis libris" wydano z dodaniem innych pism uzupełniajacych apologie problemu. W przedmowie do wydania krakowskiego. Maciej Walerian zebraz argumenty w obronie pogańskiego piśmiennictwa starozytnego, atakując zarazem niezrozumienie problemu przez niektóre ́́rodowiska teologiczne. List Hieronima, zawierający równieź obszerna apologię studiów nad piśmiennictwem pogańskim, został uzupełniony przez znakomitego humanistę Lorenzo Valle /+ 1457/ podkreśleniem 1ch niezbędności.

We wspomnianej wyżej przedmowie Praedicatorius wskazuje na trzech szermierzy 1 obrońców artes - Bazylego, który poucza jak korzystać z piśmiennictwa pogańskiego, Hieronima, który myjaśnia, jak nalezy posługiwać sie tym piśmiennictwem 1 mykorzystywać je dla celów teologicznych 1 Vallę, niestrudzonego bojownika sztuk wyzwolonych. W zamieszczonym liście "Ilieronymus magno oratori Romanon Doktor Kościoła oświadcza, ze od najdawniejszych czasów korzystano $w$ piśmiennictwie religijnym $z$ bogactwa myśli pogańskiej. List ten był odpowiedzia na zarzuty oratora rzymskiego, który wytykaz Hieronimowi, iz ten, korzystając z piśmiennictwa pogańskiego, kala Kośció chrześc1jańsk1. Powyzsze dzieło zachowało sie w unikalnym egzemplarzu w Blbllotece Czartoryskich w Krakowie ${ }^{35}$.

IF zakonczeniu pydawanego dzieła Maciej Walerian umieścil søój własny wstęp do "Topik" Cycerona, "którym informuje o napaściach, Jakich doznał w Akademi1. Dodatki te znacznie wzbogaciły wydanie krakowskie w stosunku do Innych wydań europejskich.

33 Czerniatowicz, art. cyt., 74.

34 Tamże, 72.

35 Sygn.'XVI. $1989 / 1$.

36 Pierwsze wydanie ukazało sie juz ok. roku 1470-1471 wenecj1. 
Swięty Bazyli Wielki nie doczekaz się w Polsce do poz. IVI w. wydrukowania zadnego swojego dzieła jako osobnego tytułu. Jego pisma stanowiły zawsze tylko jakąś część dzieła zbiorowego. Tak tez było w 1522 r., k1edy to Hieronim Wietor wydrukowal antologie zbioru modiltw dla przystępujących do komun11 ́́w. pt. "Sanctissimorum Patrum eorundemque erudit1ssimorumvirorum Basili1 Magni, Joannis Chrysostom1, Joannis Damasceni et Symeonum Metaphrastae ac Junioris Theologorum, Pauli quoque monach1 Orationes in divini Corporis communione, itemque alias quaedam dicendaen ${ }^{37}$. Estreicher mylnie podal date jej edycji na 1528 rok $^{38}$. Prostuje to ks1aqdz Jan Fijałek 1 ustala date na 1522 rok $^{39}$. Powyzsza antologia, zebrana przez Franciszka kolandella z Tarvisio, a przygotomana do druku przez profesora Akademii Krakowskiej Filipa Gundela, zapoczątkowała w Krakow1e - bez wiekszego naukowego znaczenia - studia patrystyczne. I tym razem zachowal sie tylko unikalny egzemplarz wibliotece Czartoryskich w Krakowie 40 .

To samo dzieło, lecz pod zmienionym tytułem: "Orationes quaedam devot1ssime Basilil Magni et Joannis Chrysostomi de Communione Eucharistiae"41, wytłoczono Polsce jeszcze trzy razy: dwa razy uczyniła to Helena Unglerowa w latach 15371 1540, a raz Hieronia Wietor 1539 roku. Ten ostatni zamieścil ponadto $w$ swoim wydaniu drzeworyt przedstawiający kapłana słuchającego spowiedzi, natomiast Unglerowa w edycj1 z $1540 \mathrm{r}$. umiesciła drzeworyt przedstawiajacy Chrystusa ukrzyzowanego. Po lewej stronie zbawcy stoja Matka Boza 1 św. Jan Ewangelista, a Marla Magdalena obejmuje u dołu krzyz. Po prawej stronie Chrystusa rozlega sie widok na Jerozolimę. Takie przedstawienie ukrzyzowania jest niezwykle rzadkie. Pod tytukem wydaniach z 153911540 r. znajduje sie epigram pt. "Ad Lectorem libellus per Philippum Gundelium Bolum", w którym zachęca do lektury 0jeów Kościoła ${ }^{42}$.

37 Por. Katalog $\mathrm{nr} 13$.

38 Estr. XII, 400.

39 Fijałek, art. cyt., 49.

40 Sygn. Cim. 1606/I.

41 Por. Katalog nr 23, 25127.

42 "Alter ad exemplum doceat vixisse libellus Alter ad eloquium non grave pandat 1 ter Nos luvat aethereum precibus placare tonantem Quis valeas, facile te docuisse modo. 
Juz kilka razy podczas omawiania druków z zakresu patrystyk1 przewijało sie lmię św. Jana Chryzostoma. Ten Doktor Kościoła, tak ceniony przez Erazma z Rotterdamu, doczekał się w Polsce najwięcej druków. 0 kiliku z nich była już mowa w związku z dziełamı Innych 0jeów Kościoła. Drukowanie pism św. Jana Chryzostoma mozna by podzielić na trzy okresy. Pierwszy okres - to tylko jeden druk, ale u zarania dziejóm polskiego drukarstwa, drugi - rok 1528, 1 trzec1 - lata 1538-1545.

Juz ok. 1475 r. Kasper Elyan we Wrocławiu na ostatnich 5 kartach dzleła św. Antonina z Florencj1/+1459/pt. "De instructione seu directione simplicium confessorum" wydrukował "Sermo beat1 Johannis Chrysostomi De penitencia"43. Kazanie wschodniego Doktora Kościoła odpowiadało ściśle treści dzieła głównego. Był to jednak jedyny druk śr. Jana Chryzostoma wytłoczony poza Krakowem.

Wszystkie krakowskie druki tego Ojca Kościoła były bezposrednio lub pośrednio zwizzane z Erazmem z Rotterdamu. Potwierdza to Juz wcześniej zaznaczony - mpływ Wielkiego Holendra na wydawanie dziel patrystycznych $w$ Polsce. I tym razem pryn w tłoczeniu tych ksiazek wiódł Hieronim Wietor. Na 12 druków Chryzostoma, 10 wydrukował włánie Wietor, a 2 Maciej Szarfenberg.

0 wydrukowanie u Wietora w 1528 r. pisma Chryzostoma pt. "De beato Philogonio deque digne sumenda Eucharistia concio"44 wacińskim przekładzie-dokonanym z greki przez Erazma, postarał sie Paweł Decentius, czyli Paweł Krasowski, krewny Stanisława Hozjusza. By 1 on wówczas proboszczem kolegiaty Wszystkich Swiętych, kanonikiem krakowskim 1 sekretarzem kanclerza państwa Krzysztofa Szydłowieckiego ${ }^{45}$. Dzieło to miało za zadanie bronić sakramentu Eucharystil przed atakam1 ze strony protestantów, którzy ten Sakrament albo odrzucali albo tez inaczej interpretowali. Dzieło natomiast fw. Jana Chryzostoma potwierdzało katolicki punkt widzenia w tym względzie.

Non sum sub trivils toto haud incognita vilgo Pagina, sed Basili1, nobile lector, opus

Et qui divina verba aurea voce locutus

Me dedit, ot graece facta, latina legor".

43 Por. Katalog $\mathrm{nr} 1$.

44 Por. Katalog nr 15.

45 Fijałek, art. cyt., 78. 
F r. 1526 Erazm z Rotterdamu wydał trzy homilie św. Jana Chryzostoma, z których dwie na temat listu św. Pawła do Filipian przetłumaczył na język łaciński, a trzecłą "o królu 1 mnichu" opubl1kował tylko po grecku46. Stanisław Ilozjusz, po zapoznaniu siz z wydaniem powyzszych homilif św. Jana Chryzostoma, postanowi przetłumaczyć tę trzecia z języka greckıego na łaciński 1 wydać ja w Polsce, co uczynił Maciej Szarfenberg w 1528 r. pod greckim 1 łacińskim tytułem: "Libellus elegans in quo confert verum monachum cum principibus, divitibus ac nobilibus non huius mundi Stanislao Hosio interprete" ${ }^{47}$. Typograp poniżej tytułu umieściz drzeworyt przedstawiajacy herb biskupa krakowskiego Lodzia Piotra Tomickiego, do którego Hozjusz kieruje równiez swoja przedmowę. W przedmowie tej wskazuje m.1n. na wartośc1 moralne, tkw1ące w tekstach autorów greckich, bronl nauczania języka greckiego 1 przyznaje, ze sam nieraz korzystał z rad pisarzy starozytnych, którzy polecali przekładanie tekstów, aby nabrać wprawy w języku ${ }^{48}$. Tytuł całości przed samym tekstem tłumaczenia brzmi jednak nieco inaczej: "Comparatio Regiae potestatis, divitiarum, et nobilitatis cum Monacho, qui cum vera et christiana philosophia familiaritatem habet".

Tré́ć powyższej homilii św. Jana Chryzostoma jest niczym innym, jak obrona stanu zakonnego, który czasach rozwijającej s1e reformacji był mocno atakowany. Hozjusz jednak nie pisze, że takze Erazm by przecimnikiem zakonów Kościele $e^{49}$ I być może dlatego

46 M. Borzyszkowsk1, Materiały do twórczośc1 poetyckiej 1 dzłałalnośc1 wydawniczej Stanisława Hozjusza w latach 1522-1548. "Studia Warmińskie" 7/1970/ poz. 26.

47 Por. Katalog nr 14.

48 Borzyszkowski, art. cyt., poz. 26.

49 Książke polemizująca z poglądami Erazma z Motterdamu na temat zakonów wydał Pranciszkanin hiszpaniski Ludwik de Caravail $1529 \mathrm{r}$. W Polsce wydrukował Ja Jan Halicz w $1540 \mathrm{r}$. pt. "Apologia diluens Erasmi in sacras religiones. Praecipue assertiones Erasmi quibus in apologia respondetur". 
nie przetłumaczył tej homili1 na jezyk łacińsk1. W kazdym razie Hozjusz wykorzystuje homille Chryzostoma w walce przeciwko protestantom 1 rozpoczyna nia swoja działalnośó kontrreformacyjna, która będze prowadzil do końca swojego zycia $/+1579 /$.

Przez osiem lat, czyli do 1538 r., nie wydrukowano w Polsce zadnego dziẹza éw. Jana Chryzostoma, ohociaz czesto korzystano z jego myśl1, szczególnie w dzlełach polemioznych. Doplero we wapomnianym nytej roku Jerzy Liban /+ po 1546/ umieśc1z w smo1m dziele pt. "Ep1stola collaudatoria ad amicum Mart1num Lang1olum/, quem hortatus adversa Ecclesiae fortiter tolerare", drukowanym przez Macieja Szarfenberga, tekst przełozonego j jezyka greokiego na zaciński zywota św. Jana Chryzostoma, pt. "D1vi Joannis Chrysostomi vita ex Suidan 50 .

Jerzy Liban w 1520 r. podjał wykłady gramatyki greckiej w Akademil Krakowskiej, czym zapoczątkowaz w niej regularne studia grecystyczne. Koła uniwersyteckie, przecinne nauce Jezyka greckieo, zaatakowazy Libana jako potencjalnego szerzyciela luteranizmu. Atak1 te byly tak mocne, ze Liban musial zaniechá́ wykładów w Akademil. Oriara tych ataków padz równiez Jak juz wspominaliśmy, Maclej Walerian z Warszawy. Llban jednak powrócił na wspomniany uniwersytet dopiero 1528 r., dzieki protekcjl biskupa Plotra Tomickiego, 1 dalej kontynuowaz swoje wykłady do 1535 roku ${ }^{51}$. Wspomniany druk L1bana by $z$ jedynym tekstem na temat ś. Jana Chryzostoma, ale nie jedynym, jak sio okaze, z zakresu patrystyki.

Najwieksze jednak zasługi w tym czasie na polu popularyzacji dziez św. Jana Chryzostoma miaz inny wybitny humanista polski Marcin Kromer /+ 1589/. I7 czasie pobytu we Wroszech /1537-1540/ odnalazł on wóród rękopisón boloúskich nigdzie jeszcze nie wydrukowane homilie Jana Chryzostoma 1 wydał je częściami w przekładzle łacińskim u Hieronima Wietora w1541 11545 roku. Były to: "De divitis et paupertate", "De non contemnenda Ecclesia De1 et mysterils", "De humilitate"; "De adversa valetudine", "De Ingluvie et ebrietaten 1 "De anima" opublikowane 1541 roku" oraz "De

50 Por. Katalog nr 24.

51 H. Wyczawsk1, Liban Jerzy, w: Słownik Polskich Teologów Katolick1ch, II, Warszaw a 1982, 522.

52 Por. Katalog nr 28, 29, 30, 31, 32, 33. 
avarit1a" 1 "Orationes duae: De humilitate animi et de uxore et pulchritúdine" wydane w 1545 roku $^{53}$. Estrelcher nie odnotował jednego jeszcze wydania homili1 "De anima",którego egzemplarz \% dobrym stanie zachował siq $w$ 0ssólineum ${ }^{54}$. Na druku tym nie podano an1 Impresora, ani roku wydania. Typografem kslazk1 by jednak na pewno Wietor, na co wskazuja typowe dla tego warsztatu drukarskiego czcionki renesansowe.

Kazde z powyzszych dzlez miało swoje specyficzne cechy, nie wystepujace w Innych drukach. Homilia "De humilitate" nie posiada daty, "De non contemnenda Dei et mysteriss oratio" zawiera tylko tekst lacinski, a nie ma tekstu greckiego, do druku natomiast "De d1vitiss et paupertaten dołączył swój epigram Klemens Janickí ${ }^{55}$. To ostatnie dzieło było szczególnie cenne, poniewaz Kromer dedykowal je arcybiskupowi Plotrowi Gamratowi z racji wyniesienia go na arcybiskupstwo gnieźnieńskie w 1541 roku. Równiez następna homilie Kromer zadedykował Gamratowi, piszac wierwszych słowach dedykacj1: "En alteram Chrysostomi orationem in latinum sermonem a nobis conversam per te, Petre antistes amplissime, graece linguae ignaris pietatis sectatoribus damus, argumento ad perverga haec nostra tempora valde accomodato" /podk. J.D./. Z podkreślonych przez nas słów wynika, ze Kromer miał konkretny cel w publikowaniu pism św. Jana Chryzostoma, a mianowicie wydawaz je ze względu na niespokojne czasy spowodowane przez reformacje. Mamy więc następny przykład wykorzystania dzieł patrystycznych w toczacej $8 i_{8}$ polemice pomiedzy katolikami a protestantami. Kromer jadnak by ostroźny. Nie wymlenial Lứra ani innych reformatorów, lecz pisaz tylko o przewrotności niektórych chrześcijan, w tym także katol1ków. Uważał, ze homilie Chryzostoma nie straciły na aktualnośc1, przez co podkreślał clagłość Tradycji, atakowanej przez reformatorów.

Równiez w celach polemicznych nominat biskup chełmski 1 podkanclerzy koronny Sanuel Maciejowsk1 /+ 1550/ wydaz w 1539 r. u Wio-

53 Por. Katalog $\mathrm{nr} 36$ i 37.

54 Por. Katalog nr 38; Sygn. XVI. 6606.

55 Por. Clementis Janici poetae laureum Carmina. Ed. Ludovicus CwIkliński, Cracoviae IDXXX, 143. 
tora dzieło zbiorowe oparte na traktacie filncentego $z$ Lerynu $/+$ ok. $450 \mathrm{r.} / \mathrm{pt}$. "Pro catholicae fidel antiquitate et universitate; adversus profanas omnium haereseon novationes ilbellus, ad haec nostra tempora valde accomodatus ${ }^{56}$. Do dzieła Whentego i Lerynu wydawca dołaczy także fragment traktatu Tertuliana /+ ok. 225/ pt. "De praescriptione haereticorum" 57 .

Wydanie traktatu $\mathbb{W}_{1}$ incentego z Lerynu miało duze znaczenie podczas toczicej sie poleniki religijnej. Wincentego w tym okresie cytowano często, szczególnie gdy chodziło o podkreślente znaczenia P1sma św. I nauczanta Kościoła przy odróznianiu nauki pałszywej od prawdz1we $\mathrm{j}^{58}$.

II polskich drukarniach wydrukowane takze kilka dzieł, błędnie przypisywanych 0jcom Kościoła. Dzisłaj wiemy, ze $1 \mathrm{ch}$ prawdzimymi autorami byl1 inni pisarze. Niektórych z nich zidentyiłkowano, innych zaś jeszcze nie 1 nadaje im się przedrostek "Pselido". Takim np. dziełem jest tłumaczenie niewielkiej ksiazeczki pt. "Liber de vita christiana", wydanej przez Wietora w $1522 \mathrm{r}$. pod polskim tytułem: "Ksı̨̨i św. Augustyna biskupa hippońskiego o żyocie krześc1jańskim"59. Fragmenty tego druku odkrył w 1911 r. 1 opisał w 1914 r. Adam Chmiel ${ }^{60}$. z sześciu zachowal sie tylko ostatni arkusz druku, w zwiazku z czym nie moźna podać nazwiska tłumacza. Chmiel postauli hipoteze, ze tłumaczem byl Baltazar Opeć, znany z popularnej edycj1 "Zywota Pana Jezu Krysta". Za hipoteza ta przemawia lakt, ze omawiany przekład ukazał sie w tym samym roku 1 w tej samej drukarni, co "Żywot"61. Do dzisiaj nie jest tez do końca wyjaśniona kwestia autorstwa oryginału. Na pewno nie by nim św. Augustyn, bowiem w rozdziałach 11 i 13 istnieja wyraźne ślady pelagianizmu ${ }^{62}$.

56 Por. Katalog $\mathrm{nr} 26$.

$57 \mathrm{Na}$ kartach $\mathrm{K}_{4}-\mathrm{K}_{4}$.

58 Borzyszkowski, art. cyt., poz. 32 .

59 Por. Katalog nr 11.

60 "Ks1ęg1 św. Augustyna b1skupa h1ppońsk1ego: o zywocie chrześc1jańskim. Druk Ilieronima Wietora z $1522 \mathrm{r} \cdot / \mathrm{z}$ podobiznq/". Wydat Adam Chmiel. Uwagami Jezykowymi opatrzył J. Loś, Kraków 1914.

61 A. Bober, Pseudoaugustyriskie dzieła ascetyczne w Polsce, RTK $4 / 1957 /$ z. 2,40 .

62 Tamze. 
Przez dluzszy czas wskazywano na pelagiańskiego biskupa Fastidiugza ${ }^{63}$. Plinval 64 jako pierwszy wskazal na autorstwo samego Pelagiu8za ${ }^{65}$, co później przyjął autor znanej "Patrologi1", B. Altaner 66 .

W powyźsym druku 'Fietora, odnalezionym przez Chmiela, na trzeoh.ostatnich stronach zachowazy sie takze fragmenty z innego dziela przypisywanego d́w. Augustynow1 pt. "Liber arhortatorius, vulgo de salutaribus documentis ad quaendan comitemn67. Rzeczywistym autorem tego pisma okazal sie patriarcha Akwile1 - Paulin $/+802 / 68$, a Jego treśc1a jest zachęta do kochania Boga 1 ostrzezenie przed zgubna miłościa świata.

Estreicher Informuje, ze w 1511 r. w jednej z drukarń krakowskich miano wytłoczyd dzieło Pseudo-Dionizego Areopagity pt. "Alphabetum theologicum"69. Takze Katalog Centralny mieszczący sie - Bibliotece Narodowej w Warszawie podaje przy tytule tego dzieła "Kraków" I rok 1511, opierając się na wzmiance Estreichera. Natomiast "Polonia Typographica", najnowsze źródło wiedzy o produkcj1 starodruków, nie wymienia tego druku w swoich zestawach. Nie można nlestety zweryfikować tych zapisów, gdyz jedyny egzemplarz znajduJacy sie nlegdý́ w Bibliotece Kapitulnej w Gnieźnie zaginą; jest cakk1em prawdopodobne, ze by to produkt zagraniczny.

W interesujacyn nas okresie wytłoczono równiez dwa druki wierszowane, których autorem by 1 , jak mniemano, Laktancjusz $/+330 /$. Plerwszy z nich pt. "De resurrectione" zostal umieszczony $w$ dziele pt. "Poenitentionarius de confessione" z 1514 r., które wspólnie wytłoczyl1 Florian Ungler 1 Wolfgang Lern ${ }^{70}$. Prawdzinym autorem

63 Tamze: "Holstensius $w$ swoim wydaniu "De vita" z $1633 \mathrm{r}$. przypisał Je na podstawie notatki rękopisie z Monte Cassino, pelaglanskiemu biskupowi Fastidiuszowi z Brytanil".

64 G. Plinval, lecherches sur l'oeuvre littéraire de Pelage, "ilevue de Philologien 60/1934/, 9-42.

65 Bober, art. cyt.. 41.

66 B. Altaner, Patrologie, Freiburg 1980, 375.

67 Por. Katalog nr 12.

68 Bober, art. cyt., 42.

69 Por. Katalog nr 5.

TO Na kartach $E_{2}-B_{4}$; por. Katalog nr 7 . 
Fiersza okazal sie jednak późniejszy poeta lacinski Venantius Fortunatus $/+$ ok. $601 / /^{71}$. Ten sam wiersz przedrukowal jeszcze raz - 1528 r. Maciej Szarfenberg w addendach do dzielka Baptisty Pallavicinusa pt. "In historiam Plendae crucis in funeris Domini nostri Jesu Christin $n^{72}$.

Ostatnia grupe druków patrystycznych wytłoczonych do 1550 roku gtanowia dzieła apokryficzne. Niezwykle popularna ksiazka z tego gatunku były w wekach średnich "spistolae Senecae ad Paulum et Paul1 ad Senecann, które wytłoczył Wolfgang Lern ${ }^{73}$. N1e podaz on na druku daty, Jednak mająo na uwadze fakt, te w lataoh 1513-1514 współpracował z Unglerem, wydaje sie prawdopodobne, iz ksiazeczka ta sostaza wydana mniej wiecej w tych samych latach. N1e jest jednak wykluozone, ze mogło to byó wczéńlej, albowiem Lern przebywaz - Krakowie od 1509 roku $^{74}$. Domniemane 11sty budzizy przez wieki saufante ze względu na notatke 6́n. Hieronima " "De viris 111ustribus", gdz1e pisaz: "Lucjusz Anneusz Seneka z Korduby/H1szpan1a/, uozeń stoika Socjona 1 stryj poety Lukana, prowadzil bardzo watrzemiezliwy tryb zycia. Nie unieśc1 zbym go watalogu fílętyoh, gdyby mise do tego nie akzoniły powszechnie czytane listy Pawza do Senek1 1 Senek1 do Pawza. listach tych Seneka, mimo te by wyohowaweą Nerona 1 człowiekiem w owym czasie niezmiernie wpływowym, twierdzi, ze zyczyłby soble miec takie znaczenie wáród swoich, Jarie ma Pawel u chrześcijan. Seneka zostal przez Nerona zamordowany na dwa lata przed męczeńska fmiercia Piotra 1 Pawan75.

Nie mniej popularnym dzielem od "Listó Pawka 1 Senekin by wyrocznie "Syb1111 Erytrejskiej",które wydrukowano " Polsce $w$ dwóch opracowaniach 1 trzech wydantach. Plerwaze 1 drugle wydante ukazało s1e w latach 1528 i 1535 w warsztacie typograficznym Unglera pt. "Carmina sibyllae Erythreaeae, in quibus resurrectio corporum,

71 K. Moramsk1, Historia literatury rzymskiej, VII, Kraków 1931, 165.

12 Na kartach $\mathrm{D}-\mathrm{D}_{3}$; por. Katalog $\mathrm{nr} 17$.

73 Por. Katalog ni 6.

74 Drukarze dawnej Polsk1, 110.

75 A. Bober, Antologia patrystyczna, Krakóv 1965, 219-220, 
mutat10 saeoulorum, De1 adventus ad ludicium, praemia et supplioia hominum desoribunturn ${ }^{76}$. Pierwsza lch edycja, o której wspomina nPolonia Typographican77, niestety zaginęla; zachowały sie natomiast egzemplarze z 1535 roku.

Autorem powyzszego opracowania by 1 wpomniany juz profesor Jezyka greckiego na Uniwersytecle Jagiellorskim Jerzy Liban. W przedmowie skierowanej do Plotra Tomickiego, któremu Liban dedykuje to dzieło, nysławia biskupa za szczególne umiłowante języka greokiego 1 hebrajskiego. Liban analizuje poszczególne zdania wyrocznt, odworując się często do odpowiednich miejse w Pí́mie św., do pisarzy patrystycznych 1 autorów starozytnośc1 pogańskiej. Na podstawie słóm Sybilli udowadnia, ze przewidziała ona przyjácie Chrystusa Pana 1 Jego zmartwychwstanie.

Zupełnie Inny charakter miało opracowanie Stefana Crabeniusa pt. "Erythraeae Sybilláe de Christo mund1 Salvatoren78. Jest to krótki utwór wierszowany, dołączony do dzieła tego samego autora pt. "Historia nativitatis Domini nostri Jesu Christi", które wydrukowaz Hieronim wietor 10 stycznia 1544 roku. Jest to przypuszczalnie list Piłata do Klaudiusza Tyberiusza, wtórym ten piewszy opisuje skazanie na b́mierć Jezusa Chrystusa ${ }^{79}$.

Spogląajac na produkcje dzlez patrystycznych w Polsoe do połowy XVI wieku mozna dostrzec, ze ksiakka patrystyczna zaczęto się interesować szczególnie w dobie renesansu 1 reformacji. Ksiazzka ta miała słuzyé przede wszystkim celom kontrreformacyjnym. Ukazywała bowiem clagłość Tradycji katolickiej; tę sama doktrynę, która nie ulegała zmianom poprzez wiek1. Ponadto druk pism 0jeów Kośotoza miał ukazać wspołczesnym rolę, jaká mogli spełní pisarze staroohrześc1jańscy w XVI wieku. Tielka niewatpliwie role w upowszech-

76 Por. Katalog nr 16121.

77 Polonia Typographica saeculi sedecimi. Zbiór podobizn zasobu drukarskiego tłoczn1 polskich XVI stulecia, $z$. VII: Druga drukarnia Floriana Unglera 1521-1536. Oprac. H. Bułhak, Wrocław 1974, poz. 58 a.

78 Por. Katalog nr 35.

79 Por. J. Czerniatonicz - Cz. Mazur, Hecepoja antyku chrześc1jarisiego " Polsce. Materiaky Bibilograficzne, $t$. 1: VI-XVIII w., oz. 1: Autorzy 1 teksty, Lublin 1978, poz. 15. 
nianiu dzieł patrystycznych odegrał Erazm z Rotterdanu, a pod jego wpływem polskie koła erazmiańskie, działajace w Krakowie 1 Wrocławiu. W stosunku do drukarń krakowskich typografow1e z innych ośrodków nie wydali zbyt wielu dziel patrystycznych. Drukarze zachodni tłoczyl1 z kolel znacznie wiecej tego rodzaju dziel niz impresorzy polscy. Tym nie sprzyjały niektóre kręgi uczonych w Akadem11 Krakowsk1ej, którzy $\boldsymbol{w}$ powrocie do starozytności dopatrywali się źródeł herezj1. Dzięki Marcinowi Kromerowi wydrukowano wiele dzieł św. Jana Chryzostoma. Najwięrsza zaś zasługe w Ich tłoczeniu miał bez watpienia Hieronim Wietor. Nie naleźy takze zapominać o tym, ze wiele ówczesnych ksiazzek poświęconych innym gatunkom teologicznym róniez zawierało niemało mniejszych lub większych eragmentów pism patrystyczny ch ${ }^{80}$.

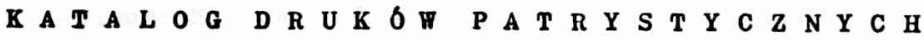
/ok. 1475-1550/

\section{WYKAZ SKRÓTOW CYTOWANEJ LITERATURY}

Cz. M. J. Czerniatowicz - Cz. Mazur, Recepcja antyku chrześcijańskiego wolsce. Materiały Bibliograficzne, t. 1: XV-XVIII w. cz. 1: Autorzy 1 teksty, Lublin 1978.

Estr. K. Estreicher, Bibliografia Polska, t. 11 nast., Kraków 1870 i nast.

Inc. Incunabula, quae in bibliothecis Poloniae asservantur, moderante A. Kawecka-Gryczowa composuerunt M. Bohonos et E. Szandorowska, Vratislaviae 1970 .

Ja. /J.D. Janocki/, Janociana sive clarorum atque 1llustrium Poloniae auctorum memoriae miscellae, t. I-III, Varsoviae 1776-1819.

PT. Polonia Typographica saeculi sedecimi. Zbiór podobizn zasobu drukarskiego tłoczni polskich XVI stulecia. Red. A. Kawecka-Gryczowa, z. I-XII, Wrocław 1959-1981.

z. III: Pierwsa drukarnia Floriana Unglera 1510-1516, oprac. H. Bułhak, Wrocław 1959. z. V: Druga drukarnia

80 Tamze. Autorzy podaja wiele tego rodzaju przykładów. 
Florlana Unglera 1521-1536, oprac. H. Bułhak, Wrocław 1964. z. VII: Druga drukarnia Floriana Unglera 1521-1536, oprac. H. Buzhak, Wrocław 1970, z. XII: Maciej Szarfenberg 15271547, oprac. H. Bułhak, Wrockaw 1981.

\section{WYKAZ SKROTOW NAZT BIBLIOTEK}

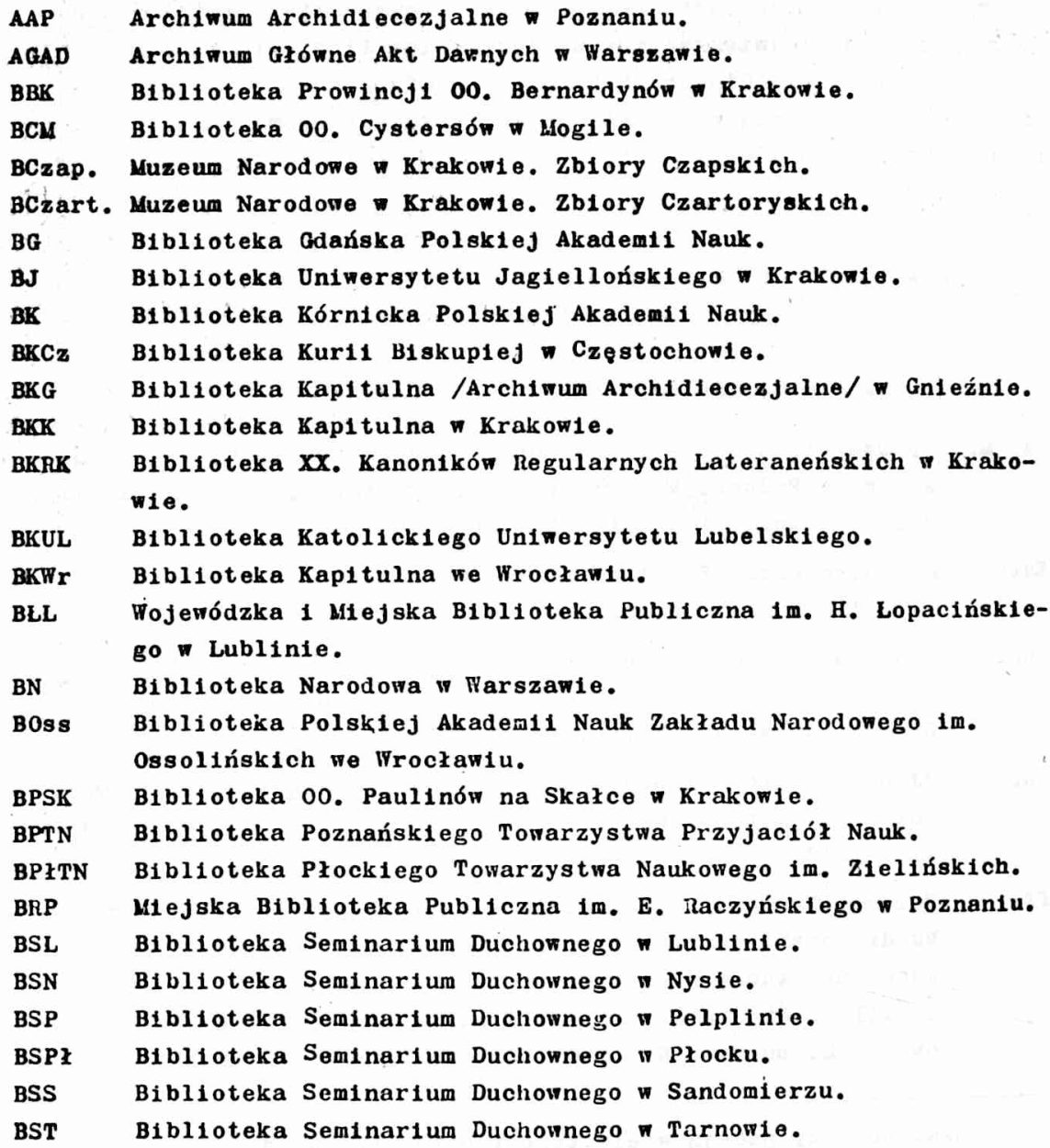


BSW Biblioteka Seminarium Duchownego we Włocławku.

BUW Biblioteka Uniwersytetu Warszawskiego.

BUWr Biblioteka Uniwersytetu Wrockawskiego.

NTT Muzeum Diecezjalne w Tarnowie.

\section{ZESTAW DRUKOW PATRYSTYCZNYCH}

1. /Ok. 1475/ JOANNES ChRYSOSTONUS: Sermo de poenitentia. /Elyan/. $4^{\circ}$.

Inc. poz. 394.

BG BJ BLL BSP BSW BUW ${ }^{2}$.

2. /0k. 1475/ AURELIUS AUGUSTINUS: Omnes libri beati Augustini Aurel11. De doctrina Christiana tres, praeter quartum qui tractat de modo pronunciandi sermones catholicos. /Straube?/. $2^{\circ}$.

Cz. M. poz. 25; Estr. XII, 293; Inc. poz. 616

AAP BCM BCzap. BCzart. BJ BK BKCZ BKG BKK BKR BKUL BOss. BPSK BSS MDT.

3. /1476-1482/ HIERONYMUS STRIDONENSIS: Eplstola ad Paulinum

Presbyterum. /Elyan/. $4^{\circ}$.

Cz. M. poz. 319; Inc. 2381.

BUHr.

4. /1477-1478/ LEONIS I PAPAE: Sermones. /Typ. Sermones Leonis I pp./. $2^{\circ}$.

Cz. M. poz. 463; Inc. poz. 3391.

BG BJ BOss. BRP BSN BST BUIYr.

5. 1511

PSEUDO-DIONISIUS AREOPAGITA: Alphabetum theologicum. Krakow? Ilaller?/. $4^{\circ}$.

Estr. XXV, Dodatek VII.

BKG /egzemplarz zaginąz/.

6. /1513-1514/ PSEUDO-SENECA: Epistolae Senecae ad Paulum et Paull ad Senecam. Lern. $4^{\circ}$.

Cz. M. poz. 13; Estr. XXVII, s. 376-377; PT. III poz. 46.

BJ /egzemplarz zaginzł/. 
7. 1514

8. 1518

9. 1519

10. 1519

11. 1522

12. 1522

13. 1522
PSEUDO-LACTANTIUS/VENANTIUS FORTUNATUS/:

De resurrectione. Ungler 1 Lern. $4^{\circ}$.

Cz. M. poz. 461; bstr. XXIV, s. 19; PT. III. poz. 53.

BCzart. BJ BN BOss. BPTN BUW BUWr.

HIERONYMUS STRIDONENSIS: Divi Eusebil Hieronymi Stridonensis Epistola ad Rusticum Monachum, qua vivendi formam praescribit, per Erasmum Roterodamum diligentissime recognita. Wietor. $4^{\circ}$.

Cz. M. poz. 320; Estr. XVIII, s. 188.

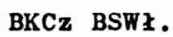

HIERONYMUS STRIDONENSIS: Aliquot Epistolae divi Eusebil Hieronymi Stridonensis, refertae saluberrimis praeceptis, ad vitam recte instituendam mire racientes, ac ab Erasmo Roterodamo pristinae integritati restitutae. Wietor. $4^{\circ}$.

Cz. M. poz. 313; Estr. XVIII, s. 188 . BBK BN BOss ${ }^{2}$.

HIERONYMUS STRIDONENSIS: Epistola divi Eusebil H1eronymi Stridonensis ad Eustochium, longe luculentissima, de custodia virginitatis. Wietor. $4^{\circ}$. Cz. M. poz. 316-317; Estr. XVIII, s. 188. Boss.

PSEUDO-AUGUSTINUS: /PELAGIUS?/: 0 zymocie krześcijańskim. AVietor/. $4^{\circ}$.

Cz. N. poz. 57; Estr. XII, s. 298. AGAD.

PSEUDO-AUGUSTINUS/PAULINUS DE AQUILEA/: Liber axhortatoris, vulgo ad salutaribus documentis ad quaendam comitem. Nietor $/ .4^{\circ}$. Jak wyżej.

SANCTISSIMOHUM PATHUM eorundemque eruditissimorum virorum Basil11 Magni, Joannis Chrysostom1, Joannis Damasceni, Simeonum Metaphrastae ac Junioris 
theologorum, Pauli quoque monach1, Orationes in divini corporis communione 1 temque allas quaedam dicendae. Per Philippum Gundelium e graeco lam primum integre translatae. Wietor. $8^{\circ}$.

Cz. M. poz. 155; Estr. XII, s. 400. BCzart.

14. 1528

JOANNES CHRYSOSTOAUS: Libellus elegans in quo confert verum monachum cum principibus, divitibus ac nobilibus. Stanislao Hosio interprete. Mać. Szarfenberg. $8^{\circ}$.

Cz. M. poz. 356; Estr. XVIII, s. 404; PT. XII, poz. 24.

BCzart. BJ BOss.

15. 1528

16. 1528

17. 1528

JOANNES CIRYSOSTOMUS: Divi Joannis Chrysostom1 Archiepiscopi Constantinopolitani de beato Philogonio, deque digne sumenda Eucharistia concio. Erasmo Roterodamo interpretae. Wietor. $8^{\circ}$. Cz. M. poz. 338; Estr. XVIII, 8. 403. BUTा BUWr.

GIERGIUS LIBANUS: Carmina Sybillae Erythraeae. Paraclesis id est Adhortatio ad Graecarum 11tterarum studiosos cum sermone de Christi resurrectione. Ungler. $8^{\circ}$. Ja. I, s. 167; PT. VII, poz. 58 a. Brak egzemplarza.

PSEUDO-LACTANTIUS/VENANTIUS FORTUNATUS/: De resurrectionis Dominicae dic. De morte oarmen horrendum. Mać. Szarfenberg. $4^{\circ}$. Cz. M. poz. 462; Estr. XXIV, s. 30; PT. XII, poz. 18 .

BCzart. BN BOss ${ }^{2}$. BHP ${ }^{2}$ BSPł.

18. 1529

AULELIUS AUGUSTINUS: Divi Auroli1 Augustini Hipponensis Episcopi. De vita christiana ad sororem suam viduam liber unus. Wietor. $4^{\circ}$. Cz. M. poz. 50; Estr. XII, s. 298. BN BSW. 
19. 1530

20. 1534

21. 1535

22. 1536

23. 1537
AURELIUS AUGUSTINUS: Divi Augustini Aureli1 de moribus ecclestae catholicae liber unus. Sub auspicio Petri Tomici ed. per Ioannem Cervum Tucholiensem. Ungler. $4^{\circ}$.

Cz. M. poz. 48; Estr. XII, s. 293; PT. V, poz. 67. Brak egzemplarza.

BASILIUS MAGNUS, HIERONYMUS STRIDONENSIS: D1V1 Basilius Magni viri sanctissimi luxta ac eloquentissimi, De evolvendis libris scriptorum gentilium libellus sane aureus et incomparabilis. Eiusdem praeterea argument1. Epistola eruditissimi divi Hieronymi ad magnum oratorem. Praefatio Lorenzo Vallae in quartum librum elegantiarum praelectio In topica Ciceronis Matthiae Valeriani Praedicatoril. Fietor. $8^{\circ}$. Cz. M. poz. 166; Estr. XII, s. 400. BCzart.

GEORGIUS LIBANUS: Carmina Sybillae Erythaeae in quibus resurrectio corporum, mutatio saeculorum, De1 adventus ad ludicium, praemia et supplicia hominum describuntur. Scholiis quae ad grammaticam attinent, additis. Paraclesis id est Adhortatio ad Graecarum litterarum studiosos cum sermone de Christi resurrectione. Ungler. $8^{\circ}$. Cz. M. poz.14; Estr. XXI, s. 253-254; PT. VII, poz. 140.

BJ BKWr.

AURELIUS AUGUSTINUS: De musica dialogi VI Erasmi abbatis logilensis auspicio editi per Sebastianum de Felstin artium baccalarium ad Sanocensis ecclesiae paroccum. Wietor. $4^{\circ}$. Cz. M. poz. 49; Estr. XII, s. 293. Brak egzemplarza.

BASILIUS MAGNUS, JOANNES CHIYSOSTOMUS: Orationes ss. Patrum Basili1 Magni et Joannis Chrysostom1, de communione Eucharist1ae. Wdowa Unglerowa. $8^{\circ}$. 
Cz. M. poz. 159; Estr. XIV, s. 130 .

BBK BCzart. $\mathrm{BJ}^{2}$ BK BLL BN ${ }^{3}$ BOss. BSPz ${ }^{2} \mathrm{BSHZ}^{2}$

BUVY BUWr.

24. 1538

25. $\quad 1539$

26.

1539

27. $\quad 1540$

28. 1541

GEORGIUS LIBANUS: Divi Joannis Chrysostomi vita ex Suida. Mać. Szarfenberg. $8^{\circ}$.

Cz. M. poz. 421 .

BN BUW.

SANCTISSIMORUM PATRUM eorundemque eruditissimorum virorum Basili1 lagni, Joannis Chrysostomi, de communione Eucharistiae. A Francisco Rholandello Tarvisiensi a graeco translatae. Wietor. $8^{\circ}$. Cz. M. poz. 156; Estr. XII, s. 401. BCzart.

VINCENTIUS LERINENSIS, TERTULLIANUS: Pro cathollcae Iidei antiquitate et universitate, adversus profanas omnium haereseon novationes libellus, ad haec nostra tempora valde accomodatus. Caetera sequens pagina indicabit. Particula quaedam ex libro Tertuliani de praescriptione haereticorum, quod contra haereticos disputandum non sit, sed corripiendi sunt tantum. Wietor. $8^{\circ}$. Cz. M. poz. 487; Estr. XXI, s. 330 . BK BKG BOss. BSN ${ }^{2}$ BUW.

BASILIUS MAGNUS, JOANNES CIIRYSOSTOAUS: Orationes quaedam devotissime Basilii Magni et Joannis Chrysostomi, De communione Eucharistiae. A Francisco Rholandello Tarvisiensi a graeco translate. Wdowa Unglerowa. $8^{\circ}$. Cz. M. poz. 157 ; Estr. XII, s. 401. BJ BOss. BSPZ BUW.

JOANNES CHiZYSOSTOMUS: Divi Joannis Chrysostomi, Archiepiscopi Constantinopolitani, De divitis et paupertate, oratio. A Martino Cromero e graece latine eacta. Wietor. $8^{\circ}$. $/ 2$ wydania/. Cz. M. poz. 339; Estr. XVIII, s. 403. BCzart. BJ B0ss ${ }^{2}$. $/ 2$ wydania/ BPrTN. 
29.

1541

JOANNES CHIYSOSTOMUS: Divi Joannis Chrysostomi, Archiepiscopt Constantinopolitani, De non contemnenda Ecclesiae De1 et mysteriis oratio, e graece in latinum versa. Martino Cromero autore. Wietor. $8^{\circ}$.

Cz. M. poz. 344; Estr. XVIII, s. 403. BCzart. Boss.

JOANNES CHRYSOSTOAUS: Divi Joannis Chrysostomi, Archiepiscopi Constantinopolitani, De humilitate oratio. A Martino Cromero interprete. Hietor. $8^{\circ}$. Cz. M. poz. 340-341; Estr. XVIII, s. 405 . BOSB. BPYTN.

31. 1541

32. 1541

33. 1541

JOANNES CIIIYSOSTUAUS: Divi Joannis Chrysostomi, Archiepiscopi Constantinopolitani, De adversa valetudine oratio. A Martino Cromero interprete. Wietor. $8^{\circ}$.

Cz. M. poz.334; Estr. XVIII, s. 406. BOss. BPITN.

JOANNES CHRYSOSTOAUS: Divi Joannis Chrysostomi, Archiepiscopi Constantinopolitani, De ingluvie et ebrietate oratio. A Martino Cromero e graeco latina facta. Wietor. $8^{\circ}$.

Cz. M. poz. 343; Estr. XVIII, s. 405. BCzart. BOss. BP $¥$ TN.

JOANNES CHMYSOSTOMUS: Div1 Joannis Chrysostomi, Archiepiscopi Constantinopolitani, oratio de anima. Martino Cromero interprete. Nietor/. $8^{\circ}$. /2 wydania/.

Cz. M. poz. 335-336; Estr. XVIII, s. 405. Boss.

AURELIUS AUGUSTINUS: Divi Aurelil Augustini Soliloquia in Del cum cognitionen, tum amorem saluberrime introducentia. Winkler. $8^{\circ}$.

Cz. M. poz. 99.

BJ Boss. BuVrr. 
STEPHANUS CREBENIIUS: Erithreae Sybillae de Christo mundi.Salvatore carmen latinis versibus donatum observatis aorostichigis. Wietor. $4^{\circ}$. Cz. M. poz. 15; Estr. XXI, s. 254; XIV, s. 444 . BCzart. BJ Boss.

36. 1545

JOANNES CHIYSOSTOMUS: Divi Joannis Chrysostomi, Archiepiscopi Constantinopolitan1, De avaritia oratio. A Martino Cromero interprete. Wietor. $8^{\circ}$. Cz. M. poz. 337 .

BSL.

37. 1545

JOANNES CHRYSOSTOMUS: Divi Joannis Chrysostomi, Archiepiscopi Constantinopolitani, Orationes duae: de humilitate animi et de uxore et pulchritudine. Martino Cromero interprete. Wietor. $8^{\circ}$. Cz. M. poz. 342; Estr. XVIII, s. 405. Brak egzemplarza.

38. B. $\mathbf{r}$. JOANNES CHKYSOSTOMUS: Divi Joannis Chrysostomi, Archlepiscopi Constantinopolitani, oratio de anima. Martino Cromero interprete. Wietor . $8^{\circ}$. Katalog Centralny Poloników w Bibliotece Narodowej warszawie. Boss. Ks. Janusz Dyl SAC - Lublin

DER DRUCK PATRISTISCHER BŬCHER IN POLNISCIEN OFFIZINEN BIS ZUR HALFTE DES 16 Jhs. /Zusammenfassung/

In polnischen offizinen sind bis zur Halfte des 16. Jhs. /etwa 1475 bis 1550 / ungefuhr 30 patristische Btlcher gedruckt worden. Ein solches Buch diente damals vor allem gegenreformatorischen Zwecken. Ausserdem sollte der Druck der Schriften von K1rchenvatern den Zeitgenossen die Rolle zeigen, welche die altchristlichen Schriftsteller 1m 16. Jh. erfulien konnten.

Eine grosse Rolle bei der Verbreitung patristischer Werke spielte Erasmus von lotterdam und die unter dessen Einfluss in Schlesien und Krakau wirkeneden polnischen Kreise seiner Anhunger. Im Verhtlinis zu den westlichen Druckereien gaben polnische Typographen nicht viele patristische Werke heraus. Dagegen waren manche Kreise von Propessoren der Krakauer Akademie, welche in der Tillckkehr zur Antike Samen der Huresie sahen. Dank Martin Kromer gab man Uberwiegend Werke von Sankt Johannes Chrysostomus heraus. Den grossten Verdienst bei deren Abdrucis hat te dagegen Hieronimus wietor. 